\title{
TINGKAT PENGUASAAN DAN PENGGUNAAN ICT (INFORMATION AND COMMUNICATION TECHNOLOGY) PADA MAHASISWA AKUNTANSI UNIVERSITAS NEGERI YOGYAKARTA
}

\author{
Mimin Nur Aisyah ${ }^{1}$
}

Fakultas Ekonomi Universitas Negeri Yogyakarta

\begin{abstract}
ABSTRAK
Penelitian ini merupakan studi deskriptif yang bertujuan untuk mengetahui tingkat penguasaan dan penggunaan ICT mahasiswa Akuntansi UNY, tingkat kepuasan serta harapan/saran mahasiswa Akuntansi UNY terhadap prodi Akuntansi UNY dalam meningkatkan ketrampilan teknologi/software mahasiswa.

Data penelitian diperoleh melalui distribusi kuesioner dalam sebuah survei. Teknik analisis data yang digunakan adalah analisis deskriptif, baik kuantitatif maupun kualitatif. Teknik deskriptif kuantitatif digunakan untuk bagian pertanyaan tertutup sedangkan teknik deskriptif kualitatif dan kuantitatif digunakan untuk bagian pertanyaan terbuka.

Berdasarkan respon dari 115 mahasiswa Akuntansi UNY angkatan 2009 dan 2010, hasil penelitian menunjukkan: (1) Tingkat penggunaan ICT cukup tinggi, dibuktikan melalui kepemilikan alat-alat berbasis IT yang cukup tinggi, pengenalan komputer dan internet lebih dari 7 tahun, mayoritas mahasiswa $(64,35 \%)$ mengakses internet setiap hari, dan penggunaan internet untuk mencari informasi mengenai tugas perkuliahan (91.30\%); (2) Tingkat penguasaan terhadap program aplikasi komputer seperti Microsoft Word, Excel, dan Power Point cukup baik, namun pada program lain khususnya software akuntansi dan statistik penguasaannya masih kurang; (3) Secara umum mahasiswa bersikap netral terkait dengan kepuasan terhadap pembekalan ketrampilan teknologi informasi/software; (4) Mahasiswa mengharapkan: peningkatan fasilitas fisik (31.75\%), penambahan muatan IT $(27.78 \%)$, pembaharuan software (14.29\%), sosialisasi dan optimalisasi e-learning (11.90\%), peningkatan kualitas dosen (9.52\%), dan penyelenggaraan pelatihan IT (4.76\%).
\end{abstract}

Kata kunci: penggunaan ICT, penguasaan ICT, kepuasan terhadap IT

\begin{abstract}
This research is a descriptive study aimed at determining the level of mastery and use of ICT among the Accounting students of Yogyakarta State University and investigating their level of satisfaction and expectations/suggestions to the Accounting department in improving student's technology skills.

Data were obtained through the distribution of questionnaires in a survey. The data analysis technique used is descriptive analysis, both quantitative and qualitative. Quantitative descriptive technique is used for close-ended questions whereas qualitative and quantitative descriptive techniques are used for the open-ended questions.

Based on the responses of 115 Accounting students from class 2009 and 2010, the results showed: (1) The level of ICT usage is high, evidenced by ownership of IT-based tools which are quite high, usage of computer and internet more than 7 years, majority of students $(64,35 \%)$ access the internet every day, and the usage of internet to search information about lecture tasks (91.30\%); (2) Mastery level of computer application programs such as Microsoft
\end{abstract}

${ }^{1}$ Staf Pengajar Jurusan P. Akuntansi Fakultas Ekonomi Universitas Negeri Yogyakarta 
Word, Excel, and Power Point are quite good, but lack of mastery in other software programs particularly the accounting and statistics programs; (3) In general, students are neutral related to their satisfaction on IT/software lecture; (4) Students expect: improved physical facilities (31.75\%), more IT contents (27.78\%), software update (14:29\%), socialization and optimization of e-learning (11.90\%), improving lecturers' quality (9:52\%), and IT training $(4.76 \%)$.

Keywords: ICT usage, ICT mastery, satisfaction with IT

\section{A. PENDAHULUAN}

Perkembangan teknologi informasi yang pesat memberikan pengaruh yang besar terhadap berbagai aspek dalam organisasi. Bukan hanya dari sisi operasional saja, namun teknologi informasi juga turut mempengaruhi strategi yang dirancang oleh organisasi; sebagian justru menggunakan teknologi informasi sebagai strategi itu sendiri. Picot et al (1996) mengemukakan bahwa teknologi informasi dianggap mampu memberikan manfaat pengurangan biaya transaksi, peningkatan output total, dan mempengaruhi hambatan fisik maupun organisasional antara organisasi dan lingkungan sekitarnya.

Perkembangan teknologi telah membawa perubahan signifikan pada dunia bisnis saat ini. Pemrosesan informasi bisnis yang semula dilakukan secara manual berubah menjadi pemrosesan informasi yang berbasis komputer. Dalam bidang akuntansi, software akuntansi banyak bermunculan dan menawarkan kemudahan untuk menghasilkan informasi yang diinginkan, yakni informasi yang dapat dipercaya, relevan, tepat waktu, lengkap, dapat dipahami dan dapat diuji.

Meskipun sempat timbul kekhawatiran bahwa munculnya teknologi informasi khususnya software akuntansi dapat menggeser peran akuntan, namun disadari bahwa kompetensi akuntansi yang dimiliki oleh seorang akuntan tidak akan bisa begitu saja digantikan oleh software akuntansi. Disinilah tantangan bagi para akuntan dan calon akuntan untuk meningkatkan kompetensinya melalui penggunaan teknologi informasi dalam menjalankan tugas dan pekerjaannya. Dengan berbagai kemudahan yang ditawarkan oleh teknologi informasi, akuntan diharapkan mampu menguasai dan mengoperasikan software akuntansi yang tersedia serta mengoptimalkan pemanfaatannya.

Penguasaan komputer dan kemampuan mengoperasikan software akuntansi menjadi salah satu kompetensi yang diajarkan pada mahasiswa prodi Akuntansi Universitas Negeri Yogyakarta. Beberapa mata kuliah didesain untuk memperkenalkan penggunaan software pada mahasiswa, yakni mata kuliah Aplikasi Komputer dan Komputer Akuntansi. Pada mata kuliah Aplikasi Komputer mahasiswa diajari berbagai 


\section{JURNAL NOMINAL / VOLUME II NOMOR I / TAHUN 2013}

kemampuan dasar komputer seperti Microsoft Office dan Visio, sedangkan pada mata kuliah Komputer Akuntansi mahasiswa belajar menggunakan software akuntansi seperti Myob dan Accurate. Pada tingkat lanjut, penggunaan software juga dikenalkan pada mahasiswa meskipun dalam kapasitas yang lebih terbatas, misalnya pada mata kuliah DBMS (Database Management System), Pengauditan PDE (Pemrosesan Data Elektronik), TPAI (Teori Portfolio dan Analisis Investasi), serta mata kuliah Statistik.

Mengingat pentingnya penguasaan software bagi mahasiswa Akuntansi selaku calon akuntan, menjadi suatu hal yang menarik untuk mengetahui tingkat penguasaan mahasiswa terhadap berbagai software akuntansi dan pendukung yang sudah diajarkan. Penguasaan terhadap teknik komputer dan software akuntansi diharapkan bisa menjadi bekal yang memadai di dunia kerja serta meningkatkan rasa percaya diri mahasiswa untuk mengoperasikan software di lingkungan tempat kerjanya nanti. Di sisi lain, perlu dilakukan evaluasi terhadap efektivitas kurikulum program studi Akuntansi UNY dalam meningkatkan kompetensi mahasiswanya dalam hal penguasaan teknologi informasi. Mahasiswa sebagai subjek belajar menjadi pihak yang merasakan dampak langsung dari kurikulum tersebut. Oleh karenanya persepsi mereka terhadap perkuliahan yang sudah dijalani menjadi salah satu indikator penting dalam penilaian efektivitas kurikulum tersebut.

Selain penggunaan ICT dalam pembelajaran aplikasi komputer dan software akuntansi dalam aktivitas perkuliahan, mahasiswa juga memanfaatkan ICT dalam kehidupan sehari-harinya. Berdasarkan pengamatan kondisi yang ada di lapangan, mahasiswa merupakan golongan yang cukup akrab dengan teknologi. Hal ini dapat dilihat dari kepemilikan alat-alat berbasis teknologi informasi seperti desktop, laptop, handphone, MP3/MP4, kamera digital, dan lain-lain.

Selain desktop dan laptop yang banyak digunakan untuk mengerjakan tugas dan aktivitas belajar mahasiswa, handphone memiliki potensi yang cukup besar untuk dimanfaatkan dalam membantu proses belajar. Smartphone yang memiliki koneksi dengan jaringan internet memungkinkan mahasiswa untuk mencari berbagai macam informasi dari e-book, e-journal, maupun sumber elektronik lainnya guna mendukung aktivitas perkuliahannya. Apalagi UNY juga sudah meluncurkan program e-learning Be-Smart sebagai suplemen untuk mendukung aktivitas belajar mengajar di kampus. Namun demikian pemanfaatan ICT untuk aktivitas belajar mahasiswa terlihat masih belum cukup optimal. Penggunaan handphone seringkali hanya terbatas pada aktivitas menelepon dan 
mengirim pesan singkat. Jikapun terkoneksi dengan internet, maka mahasiswa tampaknya lebih tertarik untuk mengakses jejaring sosial seperti Facebook dan Twitter yang memang tengah popular terutama di kalangan anak muda saat ini. Mengetahui penggunaan ICT di kalangan mahasiswa diharapkan dapat memberikan informasi sebagai bahan masukan untuk mengoptimalkan pemanfaatan ICT dalam mendukung aktivitas belajar mahasiswa.

Berdasarkan latar belakang masalah yang dikemukakan di atas, penelitian ini bertujuan untuk menginvestigasi tingkat penguasaan dan penggunaan ICT pada mahasiswa Akuntansi UNY, mengetahui tingkat kepuasan mahasiswa terhadap kurikulum prodi Akuntansi UNY serta mengeksplorasi harapan dan saran yang diberikan oleh mahasiswa terhadap program studi Akuntansi UNY dalam meningkatkan ketrampilan teknologi/software mahasiswa.

\section{B. KAJIAN LITERATUR}

\section{Akuntansi dan Teknologi Informasi}

Perkembangan teknologi informasi yang sangat pesat membawa perubahan signifikan pada praktik dunia usaha saat ini. Berbagai aspek manajerial dan organisasional tidak lepas dari pengaruh teknologi informasi. Jika dulunya sistem pemrosesan informasi dilakukan secara manual, maka saat ini pemrosesan informasi banyak dilakukan secara otomatisasi melalui program berbasis komputer. Dalam banyak hal, informasi merupakan suatu sistem informasi mengingat bahwa akuntansi mengkomunikasikan proses dalam pencatatan, penyimpanan, pemrosesan, dan pendistribusian berbagai informasi keuangan dan nonkeuangan kepada pihak-pihak yang berkepentingan.

Pengaruh IT terhadap akuntansi dapat dilihat dalam berbagai bidang akuntansi seperti akuntansi keuangan, akuntansi manajemen, pengauditan, dan perpajakan. Dalam bidang akuntansi keuangan, teknologi informasi membuat proses dalam siklus akuntansi dilakukan melalui program computer serta memungkinkan dilakukannya real-time reporting dan disediakannya interactive data (Bagranoff, Simkin, dan Strand, 2006). Dalam akuntansi manajemen contoh penerapan IT dapat dilihat pada penerapan EDI (electronic data interchange) pada sistem sediaan JIT (just in time), pengolahan informasi biaya pada sistem ABC (activity based costing), rancangan perbaikan berkelanjutan pada TQC (total quality control) serta penerapan CIM (computer-integrated manufacturing) (Sri Maharsi, 2000). Penggunaan IT memungkinkan akuntan menggunakan software perpajakan untuk mengolah data dan mempertimbangkan berbagai strategi pajak. 


\section{JURNAL NOMINAL / VOLUME II NOMOR I / TAHUN 2013}

Penggunaan sistem terkomputerisasi juga membuat auditor harus menyesuaikan metode auditnya dengan mengembangkan pendekatan audit dalam lingkungan elektronik baik yang bersifat audit around computer maupun audit through computer.

Penguasaan teknologi informasi menjadi hal yang penting bagi akuntan untuk dapat melaksanakan pekerjaan dan tugasnya dengan baik. Bagranoff, Simkin, dan Strand (2006) mengemukakan enam alasan mengapa teknologi informasi penting bagi para akuntan, antara lain: (1) Teknologi informasi haruslah compatible dengan dan mendukung komponen lain dalam sebuah sistem informasi akuntansi sehingga akuntan harus memiliki kemampuan untuk melakukan analisis sistem; (2) Akuntan seringkali harus membantu klien mereka dalam membuat keputusan mengenai pembelian hardware maupun software; (3) Dalam mengaudit sistem yang terkomputerisasi, auditor harus memahami sistem otomatisasi dan pengendaliannya serta mampu mengidentifikasi kekuatan dan kelemahan suatu sistem informasi berbasis komputer; (4) Akuntan sering diminta mengevaluasi efisiensi dan efektivitas sistem sehingga diperlukan pemahaman tentang kelebihan dan kekurangan sistem yang digunakan serta pengetahuan tentang teknologi alternatif yang memiliki kinerja lebih baik; (5) Teknologi informasi akan mempengaruhi cara kerja akuntan di masa datang, antara lain melalui cara baru pengumpulan dan pencatatan informasi, sistem komunikasi, jenis hardware dan software, bahkan jenis audit baru; dan (6) Memahami pengaruh teknologi informasi terhadap sistem akuntansi dibutuhkan untuk berhasil dalam sebagian besar ujian sertifikasi akuntan seperti CPA (Certified Public Accountant) dan CMA (Certified Management Accountant).

Dengan demikian, meningkatkan kompetensi akuntansi dengan penguasaan teknologi informasi menjadi suatu tantangan baru yang harus dihadapi para akuntan/calon akuntan. Mereka diharapkan mampu membuka diri terhadap informasi baru dan memperkaya wawasan di bidang ilmu lain termasuk teknologi informasi tanpa menjadi counterproductive terhadap detail teknis dari teknologi informasi tersebut (Setyarini Santosa, 2002).

\section{ICT dalam Pendidikan}

Teknologi Informasi dan Komunikasi (Information and Communication Technology), yang terdiri atas teknologi informasi dan teknologi komunikasi, mampu menghasilkan teknologi unggul yang berperan penting dalam pemrosesan, manipulasi, pengelolaan dan transfer data antar perangkat/media. Pengaruh ICT telah dirasakan di 
hampir seluruh aspek kehidupan, termasuk di dalamnya di dunia pendidikan. Pengenalan komputer sebagai alat yang memungkinkan akses, transmisi, pemrosesan, dan manipulasi informasi telah menunjukkan peluang untuk memanfaatkan komputer dalam pendidikan karena keduanya berhubungan dengan informasi. Meskipun demikian, untuk mendapatkan manfaat yang optimal dari teknologi, kita harus bergerak dari information-centric view dan menggunakan teknologi untuk mengubah pendidikan melalui pendekatan baru yang akan menciptakan knowledge society, atau bahkan lebih maju lagi, untuk menciptakan creative society (Resnick, 2002).

ICT mempunyai potensi untuk mengubah pendidikan dan pembelajaran melalui dua cara penting, yaitu: (1) melakukan hal-hal yang telah kita lakukan dengan lebih cepat, lebih fleksibel, dan lebih efisien dengan akses yang lebih luas, dan (2) melakukan hal-hal yang belum dapat kita lakukan atau melakukannya dengan cara-cara yang berbeda dari sebelumnya (Roca et al, 2006).

Murphy dan Greenwood (1998) dalam Agboola mengemukakan bahwa penggunaan ICT oleh guru dan siswa dalam pembelajaran masih sangat kurang. Masalah ini merupakan masalah lazim dijumpai di berbagai belahan dunia. Berbagai penjelasan dari hasil pelbagai penelitian mengenai fenomena ini dikutip lebih lanjut oleh Agboola, antara lain: kurangnya ketersediaan dan atau kurangnya aksesibilitas sumber daya ICT di sekolah, langkanya kesempatan untuk menggunakan komputer, kurangnya pengalaman dan pelatihan untuk menggunakan ICT, kurangnya motivasi dan dorongan guru untuk menggunakan ICT, serta masih rendahnya tingkat kepercayaan diri dari guru dan siswa terkait dengan kemampuan komputernya.

Alat-alat berbasis ICT seperti TV, radio, komputer, kamera digital, dan lain-lain telah begitu akrab dalam kehidupan sehari-hari masyarakat kita, termasuk dalam kehidupan mahasiswa yang merupakan kelompok terpelajar dan melek teknologi. Hal ini mengindikasikan adanya potensi yang besar untuk memanfaatkan ICT dalam aktivitas belajar mahasiswa. Komputer sepertinya merupakan alat teknologi yang paling intens digunakan dalam aktivitas belajar, yaitu untuk mengerjakan tugas kuliah, presentasi di kelas, serta memanfaatkan akses internet untuk mencari informasi yang berkaitan dengan perkuliahan.

Selain komputer dan internet, smartphone menawarkan jalur komunikasi dan informasi yang lebih fleksibel. Meskipun demikian, ada kecenderungan bahwa kepemilikan ICT yang begitu marak di kalangan mahasiswa belum diimbangi dengan 


\section{JURNAL NOMINAL / VOLUME II NOMOR I / TAHUN 2013}

pemanfaatan ICT untuk tujuan edukasi. ICT lebih banyak dimanfaatkan sebagai media komunikasi, sosialisasi, dan hiburan. Oleh karenanya diperlukan suatu usaha untuk memotivasi penggunaan ICT untuk menunjang aktivitas belajar sehingga mampu meningkatkan kompetensi di bidang masing-masing.

\section{Kerangka Berpikir}

Perkembangan teknologi telah membawa perubahan signifikan pada dunia bisnis dan pendidikan. Secara khusus, perubahan pemrosesan informasi bisnis secara manual ke pemrosesan informasi yang berbasis komputer memberikan pengaruh nyata dalam bidang akuntansi, baik akuntansi keuangan, akuntansi manajemen, pengauditan mapun perpajakan. Berbagai software akuntansi menawarkan kemudahan untuk menghasilkan informasi yang diinginkan, yakni informasi yang dapat dipercaya, relevan, tepat waktu, lengkap, dapat dipahami dan dapat diuji.

Kehadiran teknologi informasi seyogyanya disikapi secara positif oleh para akuntan/calon akuntan. Teknologi informasi memang dapat mengancam kedudukan karyawan tingkat bawah dengan menggantikan tugas mereka, namun teknologi informasi juga menyediakan kesempatan kerja baru bagi knowledge worker yang memenuhi kualifikasi. Hal ini menunjukkan tantangan baru bagi akuntan untuk meningkatkan kompetensinya melalui penggunaan teknologi informasi. Dengan berbagai manfaat dan kemudahan yang ditawarkan oleh teknologi informasi, akuntan diharapkan mampu menguasai dan mengoperasikan software akuntansi yang tersedia serta mengoptimalkan pemanfaatannya.

Penguasaan komputer dan kemampuan mengoperasikan software akuntansi menjadi salah satu kompetensi yang diajarkan pada mahasiswa prodi Akuntansi Universitas Negeri Yogyakarta. Beberapa mata kuliah didesain untuk memperkenalkan penggunaan software pada mahasiswa, namun perlu dilakukan evaluasi terhadap efektivitas kurikulum program studi Akuntansi dalam meningkatkan kompetensi mahasiswanya dalam hal penguasaan teknologi informasi. Persepsi mahasiswa yang ditunjukkan oleh tingkat kepuasannya dapat digunakan sebagai salah satu sumber dalam penilaian efektivitas kurikulum tersebut.

Selain pembelajaran dan penggunaan ICT melalui kurikulum program studi Akuntansi, perlu dilakukan usaha untuk mendorong pemanfaatan ICT di luar kelas untuk meningkatkan aktivitas belajar dan kompetensi mahasiswa. Hal ini dimungkinkan 
mengingat mahasiswa merupakan golongan muda yang relatif akrab dengan teknologi. Sebagai langkah awal, diperlukan informasi terkait kepemilikan dan pola penggunaan ICT dalam kehidupan sehari-hari mahasiswa.

Berikut ini adalah pertanyaan penelitian yang diajukan dalam penelitian ini:

1. Bagaimana tingkat penguasaan ICT (information and communication technology) pada mahasiswa Akuntansi Universitas Negeri Yogyakarta?

2. Bagaimana tingkat penggunaan ICT (information and communication technology) pada mahasiswa Akuntansi Universitas Negeri Yogyakarta?

3. Bagaimana tingkat kepuasan mahasiswa Akuntansi Universitas Negeri Yogyakarta terhadap kurikulum program studi Akuntansi Universitas Negeri Yogyakarta dalam meningkatkan ketrampilan teknologi/software-nya?

4. Bagaimanakah harapan/saran yang diberikan oleh mahasiswa Akuntansi Universitas Negeri Yogyakarta terhadap program studi Akuntansi Universitas Negeri Yogyakarta dalam meningkatkan ketrampilan teknologi/software mahasiswa?

\section{METODE PENELITIAN}

\section{Jenis Penelitian}

Penelitian ini merupakan studi deskriptif (descriptive study) yang bertujuan untuk mengetahui bagaimana tingkat penguasaan dan penggunaan ICT pada mahasiswa prodi Akuntansi UNY, tingkat kepuasan terhadap kurikulum prodi dalam meningkatkan ketrampilan teknologi informasi sekaligus mengeksplorasi saran/masukan dari mahasiswa mengenai hal tersebut.

\section{Subjek dan Objek Penelitian}

Penelitian ini merupakan survei yang melibatkan mahasiswa Akuntansi di Fakultas Ekonomi Universitas Negeri Yogyakarta sebagai subjek penelitian. Objek penelitiannya adalah tingkat penggunaan dan penguasaan ICT serta kepuasan mahasiswa. Responden adalah mahasiswa Akuntansi UNY angkatan 2009 dan 2010 karena mereka sudah mengambil mata kuliah Aplikasi Komputer dan sedang/sudah mengambil mata kuliah Komputer Akuntansi yang memperkenalkan mahasiswa pada berbagai macam software akuntansi.

\section{Teknik Pengumpulan Data}


Data yang diperlukan dalam penelitian ini adalah data primer, yaitu data yang diperoleh dari sumber asli yang dikumpulkan secara langsung oleh peneliti. Untuk memperoleh data primer tersebut peneliti menggunakan metode survei dan mengumpulkan data melalui distribusi kuesioner. Kuesioner merupakan seperangkat pertanyaan yang dimodifikasi sesuai dengan variable yang ingin diukur oleh peneliti.

Dalam kuesioner ditanyakan data responden yang meliputi usia, gender, dan angkatan mahasiswa. Tingkat penggunaan ICT mahasiswa diukur melalui kepemilikan alat-alat berbasis teknologi, akses internet dan frekuensinya, serta pemanfaatan layanan ICT yang disediakan oleh UNY. Pola penggunaan internet diukur dengan 12 item pertanyaan yang diadaptasi dari Selwyn (2008). Penguasaan aplikasi komputer dan software diukur dengan 12 item pertanyaan yang dimodifikasi dari Lai (2008). Kepuasan mahasiswa terhadap perkuliahan diukur dengan 4 item pertanyaan yang diadaptasi dari Lai (2008). Terakhir, pertanyaan terbuka diberikan untuk mengeksplorasi harapan dan saran mahasiswa terkait muatan IT pada kurikulum prodi Akuntansi UNY maupun peningkatan ketrampilan IT/software mahasiswa.

\section{Teknik Analisis Data}

Teknik analisis data yang digunakan adalah analisis deskriptif, baik kuantitatif maupun kualitatif. Teknik deskriptif kuantitatif digunakan untuk bagian pertanyaan tertutup sedangkan teknik deskriptif kualitatif dan kuantitatif digunakan untuk bagian pertanyaan terbuka. Mengingat tujuan penelitian ingin memaparkan kondisi yang ada di lapangan, maka data dianalisis secara sederhana dengan menyajikannya dalam bentuk frekuensi dan tabulasi data. Hal ini sesuai dengan pendapat Gorard (2001) sebagaimana dikutip dalam Sewlyn (2008) bahwa salah satu alasan pokok yang mendasari tantangan terhadap kualitas dan relevansi penelitian di bidang pendidikan adalah penggunaan pengujian statistik yang over-use dan tidak tepat, permasalahan dalam tingkat pengukuran, dan kebingungan antara design error dan random variation.

\section{HASIL PENELITIAN}

\section{Deskripsi Responden Penelitian}

Sebanyak 181 kuesioner didistribusikan kepada mahasiswa Akuntansi FE UNY angkatan 2009 dan 2010. Dari kuesioner yang dibagikan, sebanyak 128 kuesioner diisi dan dikembalikan, namun dari jumlah tersebut hanya 115 kuesioner yang dapat diolah dan 
dianalisis lebih lanjut karena sebanyak 13 kuesioner tidak diisi dengan lengkap. Berikut ini adalah tabel yang berisi tentang identitas responden penelitian:

Tabel 1.Identitas Responden

\begin{tabular}{|c|c|c|c|}
\hline No & \multicolumn{1}{|c|}{ Keterangan } & Jumlah & Persentase \\
\hline 1 & Usia: & 49 & $42.61 \%$ \\
& a. Laki-laki & 66 & $57.39 \%$ \\
\hline 2 & b. Perempuan & & \\
& Usia: & 6 & $5.22 \%$ \\
& a. 18-19 tahun & 94 & $81.74 \%$ \\
& b. 20-21 tahun & 15 & $13.04 \%$ \\
\hline 3 & Tahun masuk Akuntansi UNY: & & \\
& a. 2009 & 56 & $48.70 \%$ \\
& b. 2010 & 59 & $51.30 \%$ \\
\hline
\end{tabular}

\section{Tingkat Penggunaan ICT}

\section{a. Kepemilikan Alat berbasis ICT}

Berdasarkan data yang diperoleh, handphone menjadi alat yang paling banyak dimiliki oleh responden, yakni mencapai 97,39\%. Jumlah ini disusul oleh kepemilikan televisi $(86,96 \%)$, laptop $(86,09 \%)$ dan radio $(62,61 \%)$. Selain memiliki laptop, sebagian mahasiswa $(42,61 \%)$ juga memiliki komputer (desktop). Dalam jumlah yang lebih kecil, kamera digital (37,39\%) dan MP3/MP4 player (28,70\%) juga menjadi bagian dari properti berbasis ICT yang dimiliki oleh responden penelitian ini. Hal ini menunjukkan bahwa mahasiswa yang menjadi responden penelitian merupakan golongan yang aktivitas sehariharinya cukup akrab dengan alat-alat berbasis ICT. Gambar 1 berikut ini menunjukkan tingkat kepemilikan alat-alat berbasis teknologi komunikasi dan informasi dari responden penelitian ini. 


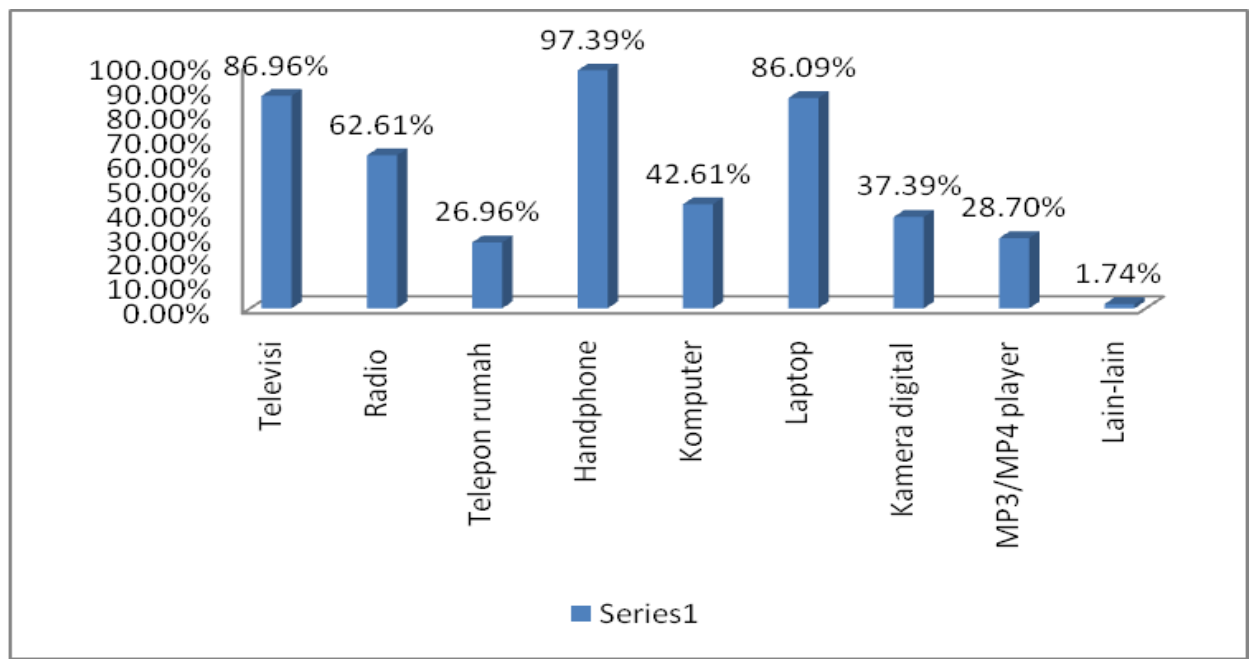

Gambar 1.Kepemilikan Alat berbasis ICT

\section{b. Penggunaan ICT}

Data penelitian menunjukkan bahwa responden sudah cukup lama mengenal dan menggunakan komputer maupun internet. Hal ini terlihat dari lamanya penggunaan komputer dan internet yang sebagian besar berkisar pada 5-7 tahun $(41.74 \%)$ dan lebih dari 7 tahun (46,09\%). Pemanfaatan internet yang cukup intens ditunjukkan oleh frekuensi penggunaan internet sebagian besar responden $(64,35 \%)$ yang menyatakan mengakses internet setiap hari. Sejumlah 28,70\% responden mengaku mengakses internet dalam frekuensi yang tidak bisa ditentukan, sementara sebagian kecil responden lainnya mengaku mengakses internet 2-3 kali seminggu $(6,09 \%)$ dan seminggu sekali $(1,74 \%)$.

Komputer/laptop di rumah serta handphone menjadi alat yang paling sering digunakan untuk mengakses internet, masing-masing sebesar $74.78 \%$ dan $73.04 \%$. Meskipun cukup banyak responden yang mengakses hot spot di kampus (49.57\%), jumlahnya masih lebih kecil dibandingkan akses internet melalui warnet (57.39\%). Selain mendapatkan pembelajaran mengenai software dan aplikasi komputer dari perkuliahan, sebagian besar responden mengaku mempelajari software secara otodidak/mandiri $(85.22 \%)$ dan belajar dari teman $(69.57 \%)$.

Data mengenai penggunaan ICT oleh responden penelitian dapat dilihat pada tabel di bawah ini. 
Tabel 2. Penggunaan ICT

\begin{tabular}{|c|c|c|c|}
\hline No & Keterangan & Jumlah & Persentase \\
\hline 1 & $\begin{array}{l}\text { Periode penggunaan komputer dan } \\
\text { internet } \\
\begin{array}{l}\text { a. }<2 \text { tahun } \\
\text { b. } 3-4 \text { tahun } \\
\text { c. } 5-7 \text { tahun } \\
\text { d. }>7 \text { tahun }\end{array}\end{array}$ & $\begin{array}{c}1 \\
14 \\
48 \\
53 \\
\end{array}$ & $\begin{array}{c}0.87 \% \\
12.17 \% \\
41.74 \% \\
46.09 \% \\
\end{array}$ \\
\hline 2 & $\begin{array}{l}\text { Frekuensi akses internet } \\
\text { a. Setiap hari } \\
\text { b. 2-3 kali seminggu } \\
\text { c. Seminggu sekali } \\
\text { d. Tak tentu }\end{array}$ & $\begin{array}{c}74 \\
7 \\
2 \\
33 \\
\end{array}$ & $\begin{array}{c}64.35 \% \\
6.09 \% \\
1.74 \% \\
28.70 \% \\
\end{array}$ \\
\hline 3 & $\begin{array}{l}\text { Sarana mengakses internet } \\
\text { a. Komputer/Laptop di rumah } \\
\text { b. Laptop dengan hot spot kampus } \\
\text { c. Handphone } \\
\text { d. Warung internet } \\
\text { e. Lain-lain }\end{array}$ & $\begin{array}{l}85 \\
57 \\
84 \\
66 \\
6 \\
\end{array}$ & $\begin{array}{c}74.78 \% \\
49.57 \% \\
73.04 \% \\
57.39 \% \\
5.22 \% \\
\end{array}$ \\
\hline 4 & $\begin{array}{l}\text { Tempat memperoleh ketrampilan } \\
\text { a. Lembaga kursus } \\
\text { b. Teman } \\
\text { c. Otodidak/belajar sendiri } \\
\text { d. Lain-lain }\end{array}$ & $\begin{array}{l}11 \\
80 \\
98 \\
17 \\
\end{array}$ & $\begin{array}{c}9.57 \% \\
69.57 \% \\
85.22 \% \\
14.78 \%\end{array}$ \\
\hline
\end{tabular}

\section{c. Pemanfaatan Layanan ICT UNY}

Secara khusus, penelitian ini ingin mengetahui tingkat penggunaan berbagai fasilitas/layanan berbasis IT yang disediakan oleh UNY di kalangan mahasiswa prodi Akuntansi. Berikut ini adalah tabel yang menunjukkan tingkat akses dan pemanfaatan layanan tersebut.

Tabel 3.Pemanfaatan Layanan ICT UNY

\begin{tabular}{|c|l|l|c|c|c|c|}
\hline No & \multicolumn{1}{|c|}{ Fasilitas } & $\begin{array}{c}\text { Tidak } \\
\text { pernah }\end{array}$ & Jarang & $\begin{array}{c}\text { Kadang- } \\
\text { kadang }\end{array}$ & Sering & Selalu \\
\hline 1 & SIAKAD & $0.00 \%$ & $15.65 \%$ & $46.96 \%$ & $35.65 \%$ & $1.74 \%$ \\
\hline 2 & Website UNY & $1.74 \%$ & $33.91 \%$ & $39.13 \%$ & $25.22 \%$ & $0.00 \%$ \\
\hline 3 & $\begin{array}{l}\text { Website Prodi Akuntansi } \\
\text { UNY }\end{array}$ & $6.09 \%$ & $36.52 \%$ & $40.87 \%$ & $16.52 \%$ & $0.00 \%$ \\
\hline 4 & E-learning Be Smart & $27.83 \%$ & $60.00 \%$ & $11.30 \%$ & $0.87 \%$ & $0.00 \%$ \\
\hline 5 & $\begin{array}{l}\text { E-journal (misal: EBSCO, } \\
\text { PROQUEST, dll) }\end{array}$ & $45.22 \%$ & $41.74 \%$ & $10.43 \%$ & $2.61 \%$ & $0.00 \%$ \\
\hline 6 & Pojok Bursa FE UNY & $73.04 \%$ & $21.74 \%$ & $5.22 \%$ & $0.00 \%$ & $0.00 \%$ \\
\hline
\end{tabular}

SIAKAD (Sistem Informasi Akademik) menjadi layanan IT yang paling sering dimanfaatkan oleh responden yakni sebanyak 35,65\%, bahkan 1,74\% responden 


\section{JURNAL NOMINAL / VOLUME II NOMOR I / TAHUN 2013}

menyatakan selalu mengaksesnya. Sejumlah responden lain (15.65\%) mengaku jarang menggunakannya. Tidak ada responden yang tidak pernah menggunakan SIAKAD. Hal ini dapat dipahami mengingat SIAKAD adalah sistem yang wajib digunakan oleh mahasiswa untuk memasukkan (entry) data KRS setiap semesternya.

Website UNY nampaknya belum dimanfaatkan secara optimal. Hanya 25,22\% responden yang mengaku sering mengakses website UNY. Sebanyak 39,13\% responden mengaku hanya mengaksesnya kadang-kadang saja, 33,91\% responden jarang menggunakannya, bahkan $1,74 \%$ tidak pernah mengaksesnya. Hal yang serupa juga terjadi pada website prodi Akuntansi UNY. Sebanyak 16,52\% responden mengaku sering mengakses wesite prodi Akuntansi sementara jumlah responden yang frekuensi aksesnya kadang-kadang dan jarang masing-masing mencapai 40,87\% dan $36,52 \%$. Sebanyak 6,09\% responden menyatakan tidak pernah menggunakannya.

Mayoritas mahasiswa Akuntansi UNY juga belum banyak memanfaatkan $e$ learning Be-Smart. Hal ini dapat dilihat dari $60 \%$ responden yang menyatakan jarang mengakses Be-Smart, bahkan 27,83\% responden mengaku tidak pernah mengaksesnya. Pemanfaatan e-journal yang telah disediakan oleh UNY pun masih jauh dari harapan. Sebagian besar responden, yakni 45,22\% dan 41,74\%, masingmasing menyatakan tidak pernah dan jarang mengakses e-journal UNY. Pojok Bursa FE UNY menjadi fasilitas berbasis IT yang paling minim penggunaannya oleh mahasiswa Akuntansi UNY mengingat 73,04\% responden menyatakan tidak pernah menggunakan Pojok Bursa dan sejumlah 21,74\% responden menyatakan jarang memanfaatkan Pojok Bursa.

\section{d. Penggunaan Internet}

Berdasarkan tingkat penggunaan dengan frekuensi "sering" dan "selalu", data penelitian menunjukkan bahwa internet paling banyak digunakan oleh responden untuk: (1) mengunduh/download software, film, gambar, foto, atau musik (94.78\%); (2) mencari informasi yang berkaitan dengan tugas perkuliahan (91.30\%); mengakses jejaring sosial seperti Facebook dan Twitter (88.70\%); (4) mencari informasi yang berhubungan dengan minat atau hobi (70.43\%); serta (5) mencari dan membaca berita terbaru melalui media online (69.57\%). Sebaliknya, berdasarkan frekuensi penggunaan "jarang” dan "tidak pernah", maka penggunaan internet untuk aktivitas berikut ini adalah yang paling minim, yaitu: (1) pemesanan dan pembelian 
tiket secara online (75,65\%); (2) menggunakan fasilitas online banking $(62,61 \%)$; dan (3) berbelanja barang secara online $(58,26 \%)$.

Berikut ini adalah tabel yang menunjukkan tingkat penggunaan internet oleh responden penelitian.

Tabel 4.Penggunaan Internet

\begin{tabular}{|c|l|c|c|c|c|c|}
\hline No & \multicolumn{1}{|c|}{ Uraian } & $\begin{array}{c}\text { Tidak } \\
\text { Pernah }\end{array}$ & Jarang & $\begin{array}{c}\text { Kadang- } \\
\text { kadang }\end{array}$ & Sering & Selalu \\
\hline 1 & $\begin{array}{l}\text { Saya menggunakan e-mail untuk } \\
\text { berkorespondensi. }\end{array}$ & $3.48 \%$ & $9.57 \%$ & $32.17 \%$ & $46.09 \%$ & $8.70 \%$ \\
\hline 2 & $\begin{array}{l}\text { Saya menggunakan jejaring sosial } \\
\text { seperti Facebook dan Twitter untuk } \\
\text { berkomunikasi dengan teman-teman } \\
\text { saya. }\end{array}$ & $0.87 \%$ & $0.87 \%$ & $9.57 \%$ & $53.04 \%$ & $35.65 \%$ \\
\hline 3 & $\begin{array}{l}\text { Saya menggunakan fasilitas chat- } \\
\text { room dan pesan singkat seperti } \\
\text { Yahoo Messenger dan Skype. }\end{array}$ & $13.04 \%$ & $13.91 \%$ & $38.26 \%$ & $24.35 \%$ & $10.43 \%$ \\
\hline 4 & $\begin{array}{l}\text { Saya menggunakan internet mencari } \\
\text { informasi yang berkaitan dengan } \\
\text { tugas perkuliahan. }\end{array}$ & $0.00 \%$ & $0.87 \%$ & $7.83 \%$ & $49.57 \%$ & $41.74 \%$ \\
\hline 5 & $\begin{array}{l}\text { Saya mencari dan membaca berita } \\
\text { terbaru melalui media online. }\end{array}$ & $1.74 \%$ & $3.48 \%$ & $25.22 \%$ & $45.22 \%$ & $24.35 \%$ \\
\hline 6 & $\begin{array}{l}\text { Saya memiliki pengalaman } \\
\text { menggunakan fasilitas } \text { online } \\
\text { banking. }\end{array}$ & $40.87 \%$ & $21.74 \%$ & $20.87 \%$ & $9.57 \%$ & $6.09 \%$ \\
\hline 7 & $\begin{array}{l}\text { Saya memiliki pengalaman } \\
\text { berbelanja barang secara online. }\end{array}$ & $36.52 \%$ & $21.74 \%$ & $19.13 \%$ & $14.78 \%$ & $7.83 \%$ \\
\hline 8 & $\begin{array}{l}\text { Saya memiliki pengalaman } \\
\text { pemesanan dan pembelian tiket } \\
\text { secara online. }\end{array}$ & $53.04 \%$ & $22.61 \%$ & $14.78 \%$ & $7.83 \%$ & $1.74 \%$ \\
\hline 9 & $\begin{array}{l}\text { Saya menggunakan internet untuk } \\
\text { mengunduh/download software, } \\
\text { film, gambar, foto, atau musik. }\end{array}$ & $0.87 \%$ & $0.87 \%$ & $3.48 \%$ & $53.91 \%$ & $40.87 \%$ \\
\hline 10 & $\begin{array}{l}\text { Saya menggunakan internet untuk } \\
\text { bermain } \text { online games. }\end{array}$ & $26.09 \%$ & $22.61 \%$ & $29.57 \%$ & $19.13 \%$ & $2.61 \%$ \\
\hline 11 & $\begin{array}{l}\text { Saya mencari informasi yang } \\
\text { berhubungan dengan minat atau } \\
\text { hobi saya melalui internet. }\end{array}$ & $1.74 \%$ & $6.96 \%$ & $20.87 \%$ & $48.70 \%$ & $21.74 \%$ \\
\hline 12 & $\begin{array}{l}\text { Saya browsing di internet tanpa } \\
\text { tujuan khusus. }\end{array}$ & $17.39 \%$ & $20.87 \%$ & $38.26 \%$ & $22.61 \%$ & $0.87 \%$ \\
\hline
\end{tabular}

\section{Tingkat Penguasaan Software}

Berikut ini disajikan hasil penelitian mengenai tingkat penguasaan mahasiswa Akuntansi terhadap beberapa jenis program aplikasi komputer maupun software akuntansi yang secara ringkas dapat dilihat di tabel 5. 
Tabel 5.Penguasaan Program Aplikasi Komputer dan Software Akuntansi

\begin{tabular}{|c|c|c|c|c|c|c|}
\hline No & $\begin{array}{c}\text { Program } \\
\text { Aplikasi/Software }\end{array}$ & $\begin{array}{c}\text { Sangat } \\
\text { Tidak } \\
\text { Menguasai }\end{array}$ & $\begin{array}{c}\text { Tidak } \\
\text { Menguasai }\end{array}$ & $\begin{array}{c}\text { Kurang } \\
\text { Menguasai }\end{array}$ & Menguasai & $\begin{array}{c}\text { Sangat } \\
\text { Menguasai }\end{array}$ \\
\hline 1 & Microsoft Word & $0.00 \%$ & $0.00 \%$ & $2.61 \%$ & $77.39 \%$ & $20.00 \%$ \\
\hline 2 & Microsoft Excel & $0.00 \%$ & $0.00 \%$ & $22.61 \%$ & $71.30 \%$ & $6.09 \%$ \\
\hline 3 & Microsoft Power Point & $0.00 \%$ & $0.00 \%$ & $6.09 \%$ & $84.35 \%$ & $9.57 \%$ \\
\hline 4 & Microsoft Access & $0.00 \%$ & $12.17 \%$ & $66.96 \%$ & $20.00 \%$ & $0.87 \%$ \\
\hline 5 & Microsoft Publisher & $5.22 \%$ & $24.35 \%$ & $55.65 \%$ & $13.91 \%$ & $0.87 \%$ \\
\hline 6 & Microsoft Visio & $0.87 \%$ & $8.70 \%$ & $51.30 \%$ & $38.26 \%$ & $0.87 \%$ \\
\hline 7 & Visual Basic & $12.17 \%$ & $41.74 \%$ & $41.74 \%$ & $3.48 \%$ & $0.87 \%$ \\
\hline 8 & Myob & $0.87 \%$ & $7.83 \%$ & $50.43 \%$ & $40.00 \%$ & $0.87 \%$ \\
\hline 9 & Accurate & $9.57 \%$ & $38.26 \%$ & $29.57 \%$ & $21.74 \%$ & $0.87 \%$ \\
\hline 10 & ACL & $24.35 \%$ & $59.13 \%$ & $15.65 \%$ & $0.87 \%$ & $0.00 \%$ \\
\hline 11 & Crystal Report & $28.70 \%$ & $58.26 \%$ & $13.04 \%$ & $0.00 \%$ & $0.00 \%$ \\
\hline 12 & SPSS & $6.09 \%$ & $20.87 \%$ & $53.04 \%$ & $19.13 \%$ & $0.87 \%$ \\
\hline
\end{tabular}

Program Microsoft Word, Excel dan PowerPoint tampaknya menjadi program yang paling populer dan paling dikuasai oleh mahasiswa Akuntansi UNY. Mayoritas responden menyatakan menguasai ketiga jenis program tersebut dengan baik, masingmasing sebesar $77,39 \%, 71,30 \%$, dan $84,35 \%$ responden. Sejumlah $20 \%$ responden bahkan mengaku sangat menguasai Microsoft Word, meskipun untuk Microsoft Excel masih ada 22,61\% responden yang menyatakan kurang menguasainya. Tidak ada satupun responden yang mengaku tidak menguasai maupun sangat tidak menguasai ketiga program ini.

Kondisi berbeda terjadi pada penguasaan responden terhadap tiga program lain dari Microsoft, yakni Microsoft Access, Publisher dan Visio dimana sebagian besar responden menyatakan kurang menguasai program tersebut, masing-masing sebesar 66,96\%, 55,65\%, dan 51,30\% responden. Meskipun demikian sejumlah responden menyatakan menguasai Microsoft Access (20\%), Publisher (13,91\%), dan Visio (38,26\%). Selain itu, Visual Basic juga dianggap tidak cukup familiar oleh responden. Hal ini terbukti dengan banyaknya responden yang menyatakan kurang menguasai $(41,74 \%)$, tidak menguasai $(41,74 \%)$ dan sangat tidak menguasai $(12,17 \%)$. 
Prodi Akuntansi UNY mengajarkan beberapa software Akuntansi kepada mahasiswanya seperti Myob dan Accurate serta memperkenalkan ACL dan Crystal Report. Sebanyak 40\% responden menyatakan menguasai Myob sementara 50,43\% lainnya menyatakan kurang menguasainya. Penguasaan terhadap Accurate lebih bervariasi dibandingkan Myob. Sebanyak 21,74\% responden mengaku menguasai Accurate sementara 29,57\% mengaku kurang menguasai dan 38,26\% lainnya tidak menguasainya. Tingkat penguasaan responden terhadap ACL dan Crystal Report paling rendah dibandingkan penguasaan terhadap software lainnya. Hal ini ditunjukkan dengan respon yang berkisar pada kurang menguasai, tidak menguasai, dan sangat tidak menguasai. Sebagian besar responden mengaku tidak menguasai ACL (59,13\%) maupun Crystal Report $(58,26 \%)$.

Meskipun SPSS menjadi software yang paling banyak digunakan oleh mahasiswa saat mengerjakan tugas akhir skripsi mereka, nampaknya penguasaan terhadap SPSS masih perlu ditingkatkan. Sebagian besar responden (53,04\%) menyatakan kurang menguasai SPSS, 20,87\% mengatakan tidak menguasainya, dan hanya 19,13\% responden yang mengaku menguasai SPSS. Secara umum, data penelitian ini menunjukkan bahwa penguasaan mahasiswa terhadap program aplikasi umum seperti Microsoft Word, Excel, dan Power Point sudah cukup baik, namun pada program lain khususnya software akuntansi dan statistik masih dirasa kurang.

\section{Kepuasan Mahasiswa terhadap Pengajaran ICT}

Tabel 6 di bawah ini menunjukkan tingkat kepuasan mahasiswa Akuntansi UNY terkait dengan muatan IT dalam kurikulum program studi Akuntansi UNY. 
Tabel 6.Tingkat Kepuasan Mahasiswa terhadap Pembekalan Ketrampilan IT

\begin{tabular}{|c|l|c|c|c|c|c|}
\hline No & \multicolumn{1}{|c|}{ Uraian } & $\begin{array}{l}\text { Sangat } \\
\text { Tidak } \\
\text { Puas }\end{array}$ & $\begin{array}{l}\text { Tidak } \\
\text { Puas }\end{array}$ & Netral & Puas & $\begin{array}{c}\text { Sangat } \\
\text { Puas }\end{array}$ \\
\hline 1 & $\begin{array}{l}\text { Seberapa puaskah Saudara terhadap } \\
\text { perkuliahan di prodi Akuntansi FE } \\
\text { UNY dalam mengajarkan ketrampilan } \\
\text { teknologi/software baru? }\end{array}$ & $3.48 \%$ & $39.13 \%$ & $29.57 \%$ & $27.83 \%$ & $0.00 \%$ \\
\hline 2 & $\begin{array}{l}\text { Seberapa puaskah Saudara terhadap } \\
\text { perkuliahan di prodi Akuntansi FE } \\
\text { UNY dalam meningkatkan } \\
\text { ketrampilan teknologi/software? }\end{array}$ & $3.48 \%$ & $26.09 \%$ & $36.52 \%$ & $33.91 \%$ & $0.00 \%$ \\
\hline 3 & $\begin{array}{l}\text { Seberapa puaskah Saudara terhadap } \\
\text { perkuliahan di prodi Akuntansi FE } \\
\text { UNY dalam mempersiapkan } \\
\text { penggunaan teknologi/software di } \\
\text { tempat kerja yang diinginkan? }\end{array}$ & $6.96 \%$ & $32.17 \%$ & $35.65 \%$ & $24.35 \%$ & $0.87 \%$ \\
\hline 4 & $\begin{array}{l}\text { Seberapa puaskah Saudara terhadap } \\
\text { perkuliahan di prodi Akuntansi FE } \\
\text { UNY dalam mempersiapkan } \\
\text { penguasaan teknologi /software untuk } \\
\text { studi lanjut? }\end{array}$ & $4.35 \%$ & $37.39 \%$ & $36.52 \%$ & $20.87 \%$ & $0.87 \%$ \\
\hline 5 & $\begin{array}{l}\text { Secara umum, seberapa puaskah } \\
\text { Saudara terhadap perkuliahan di prodi } \\
\text { Akuntansi FE UNY dalam membekali } \\
\text { ketrampilan teknologi } \\
\text { informasi/software? }\end{array}$ & $2.61 \%$ & $29.57 \%$ & $39.13 \%$ & $28.70 \%$ & $0.00 \%$ \\
\hline
\end{tabular}

Sebagian besar responden $(39,13 \%)$ menyatakan bahwa secara umum mereka tidak merasa puas maupun tidak puas terhadap perkuliahan di prodi Akuntansi FE UNY dalam membekali ketrampilan teknologi informasi/software. Di sisi lain, jumlah responden yang merasa puas $(28,70 \%)$ cukup sebanding dengan jumlah responden yang merasa tidak puas $(29,57 \%)$. Jika dilihat lebih detail, sikap netral dan ketidakpuasan responden terutama ditunjukkan pada kemampuan perkuliahan dalam mempersiapkan penguasaan teknologi di tempat kerja yang diinginkan dan mempersiapkan studi lanjut yang masing-masing berkisar pada angka 32\%-37\%. Sebaliknya, sikap netral (36,52\%) dan kepuasan $(33,91 \%)$ responden ditunjukkan pada kemampuan perkuliahan dalam meningkatkan ketrampilan teknologi/software. Ketidakpuasan responden justru mendominasi kemampuan perkuliahan dalam mengajarkan ketrampilan teknologi/ software kepada mahasiswa $(39,13 \%)$. 


\section{Saran Mahasiswa terhadap Konten IT}

Sebagai subjek dalam pembelajaran, mahasiswa tentu memiliki pendapat yang patut untuk dipertimbangkan dalam rangka evaluasi dan pemberian umpan balik untuk perbaikan di masa depan. Dengan tujuan untuk menggali aspirasi dari mahasiswa yang menjadi responden penelitian ini, maka di bagian akhir kuesioner diberikan sebuah pertanyaan terbuka, yaitu "Apakah saran yang ingin Saudara/i sampaikan kepada pengelola Program Studi Akuntansi FE UNY terkait dengan muatan IT pada kurikulum maupun peningkatan ketrampilan IT/software mahasiswa?".

Dari 115 orang responden, hanya 95 orang yang menjawab pertanyaan terbuka yang diajukan sementara 20 orang lainnya tidak memberikan jawaban. Setelah seluruh jawaban dianalisis, maka masukan yang diberikan kepada pengelola prodi Akuntansi UNY mengenai muatan IT pada kurikulum dan peningkatan ketrampilan IT/software mahasiswa dapat dikategorikan ke dalam 6 (enam) poin berikut ini: peningkatan fasilitas fisik, penambahan muatan IT, pembaharuan (update) software, sosialisasi dan optimalisasi e-learning, peningkatan kualitas dosen, dan penyelenggaraan pelatihan IT bagi mahasiswa.

Akses WIFI yang lambat, jumlah komputer yang lebih sedikit dari jumlah mahasiswa dan ruang laboratorium yang kurang nyaman cukup banyak dikeluhkan oleh responden. Sebagian besar responden $(31,75 \%)$ mengharapkan adanya peningkatan fasilitas fisik seperti penambahan jumlah komputer di laboratorium, optimalisasi laboratorium komputer, akses internet yang lebih mudah dan lebih cepat serta penambahan hot spot.

Muatan IT menjadi perhatian dari 27,78\% responden. Mereka menginginkan adanya penambahan muatan IT dalam kurikulum prodi, baik melalui penambahan mata kuliah khusus IT/software akuntansi maupun penambahan materi IT dalam mata kuliah yang sudah ada. Praktik IT juga diharapkan mendapat porsi yang lebih banyak dibandingkan dengan pemaparan secara teoritis.

Sebanyak 14,29\% responden mengharapkan program studi Akuntansi UNY untuk selalu memperbarui software yang dimiliki serta mengajarkan software terbaru yang relevan dengan praktik di dunia kerja. Melalui software updating, diharapkan mahasiswa dapat menguasai berbagai software terbaru sehingga memiliki nilai tambah untuk bersaing di bursa kerja. 
Sekalipun e-learning UNY sudah diperkenalkan selama beberapa tahun terakhir, namun penggunaannya dalam kegiatan belajar mengajar belum cukup optimal. Sebagian responden $(11,90 \%)$ menginginkan optimalisasi e-learning baik dari sisi sosialisasi maupun pemanfaatan e-learning oleh dosen dalam perkuliahan.

Peningkatan kualitas dosen dari sisi penguasaan IT juga menjadi perhatian oleh setidaknya 9,52\% responden. Dosen diharapkan mampu mengajarkan IT dengan lebih baik, bahkan bila perlu didatangkan dosen yang memiliki keahlian khusus di bidang IT. Terakhir, responden $(4,76 \%)$ juga mengharapkan diselenggarakannya pelatihan khusus IT bagi mahasiswa untuk menambah ketrampilan mereka.

Gambar 2 di bawah ini menyajikan data mengenai harapan dan saran yang disampaikan oleh para mahasiswa Akuntansi UNY yang menjadi responden penelitian ini.

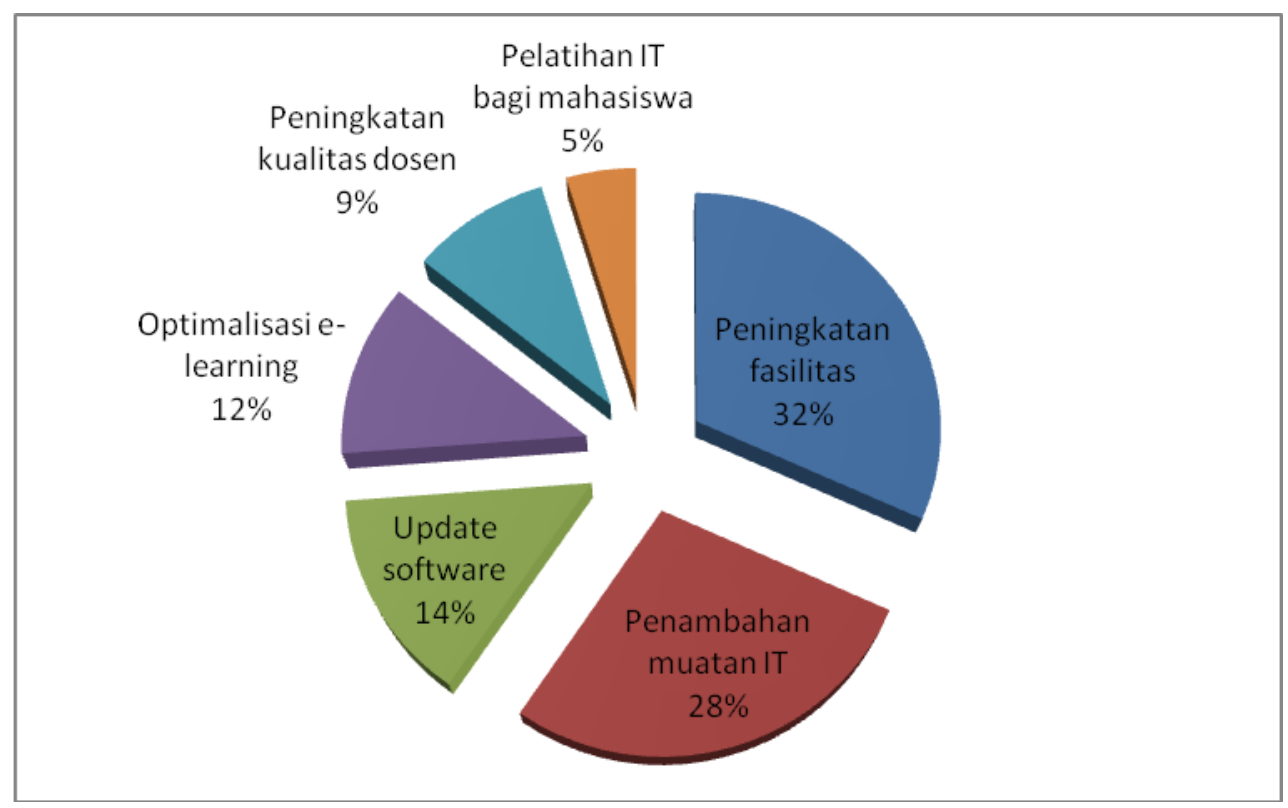

Gambar 2. Saran mahasiswa mengenai muatan IT

\section{E. PEMBAHASAN}

\section{Tingkat Penggunaan ICT}

Mahasiswa Akuntansi UNY nampaknya merupakan golongan yang cukup akrab dengan teknologi. Hal ini dapat dilihat dari jangka waktu pengenalan komputer dan internet yang cukup lama, frekuensi dan akses internet yang memadai serta kepemilikan alat-alat berbasis ICT yang cukup lengkap. Handphone menjadi alat elektronik yang dimiliki oleh hampir seluruh responden $(97,39 \%)$ sehingga menjadi gadget yang paling populer di kalangan mahasiswa. Jika selama ini handphone lebih banyak digunakan untuk 


\section{JURNAL NOMINAL / VOLUME II NOMOR I / TAHUN 2013}

kepentingan komunikasi antara mahasiswa, dosen dan program studi yang berkaitan dengan manajemen kegiatan perkuliahan, maka sudah selayaknya kepemilikan handphone ini dapat lebih dioptimalkan untuk tujuan pembelajaran. Hal ini didukung oleh data yang memperlihatkan bahwa akses internet melalui handpone dilakukan oleh 73,04\% responden.

Internet diyakini sangat bermanfaat dalam penyebaran informasi, termasuk untuk kepentingan pendidikan. Data yang diperoleh dari penelitian ini cukup menarik, yakni 91,30\% responden mengaku menggunakan internet untuk mencari informasi yang berkaitan dengan tugas perkuliahan. Jumlah ini lebih besar dari kecenderungan responden memanfaatkan internet untuk mengakses jejaring sosial seperti Facebook dan Twitter $(88,70 \%)$ yang akhir-akhir ini menjadi trend di kalangan anak muda. Hal ini menunjukkan bahwa mahasiswa telah mampu memanfaatkan internet untuk mendukung kegiatan akademisnya. Kondisi ini merupakan suatu hal yang menggembirakan dan harus dimanfaatkan untuk mengoptimalkan proses pembelajaran. Melalui internet mahasiswa dapat mengakses berbagai macam sumber pembelajaran yang tersedia kapan saja dan dimana saja sehingga tidak hanya tergantung pada aktivitas belajar di kelas. Dengan demikian, dosen dapat berperan sebagai fasilitator dalam proses pembelajaran dan model student-centered teaching dapat dioptimalkan pelaksanaan dan manfaatnya.

Sayangnya, pemanfaatan fasilitas ICT yang telah disediakan oleh UNY justru masih minim. Hal ini dapat dilihat pada rendahnya akses responden terhadap website UNY, website prodi Akuntansi, e-learning, e-journal, dan Pojok Bursa. Diperlukan sosialisasi yang lebih luas kepada mahasiswa maupun dosen mengenai keberadaan fasilitas tersebut, penyelenggaraan pelatihan dan program lain yang mendukung pemanfaatannya, termasuk perlunya insentif baik kepada dosen, program studi, maupun mahasiswa yang secara aktif menggunakan berbagai fasilitas ICT tersebut.

Peran serta aktif dosen dan institusi di berbagai level (program studi, jurusan, fakultas, universitas) menjadi salah satu faktor kunci dalam pemanfaatan internet dan fasilitas berbasis ICT di UNY. Sebagai contoh, rendahnya penggunaan e-learning BeSmart yang jarang digunakan $(60 \%)$ dan bahkan tidak pernah digunakan oleh responden $(27,83 \%)$ diduga kuat disebabkan oleh minimnya pemanfaatan e-learning oleh dosen dalam aktivitas pembelajaran. Rendahnya akses terhadap e-journal juga dimungkinkan terjadi karena kurangnya sosialisasi serta dorongan untuk mengakses artikel-artikel penelitian dalam tugas-tugas kuliah maupun penulisan tugas akhir mahasiswa. 


\section{JURNAL NOMINAL / VOLUME II NOMOR I / TAHUN 2013}

\section{Tingkat Penguasaan Software}

Secara umum, penguasaan mahasiswa Akuntansi UNY terhadap program aplikasi umum seperti Microsoft Word, Excel, dan Power Point sudah cukup baik, namun pada program lain khususnya software akuntansi dan statistik penguasaannya masih kurang. Hal ini dimungkinkan karena alokasi waktu pengajaran software akuntansi yang cukup pendek, penggunaan software akuntansi hanya pada mata kuliah praktik, serta kurangnya integrasi antara mata kuliah praktik IT dengan mata kuliah lain yang relevan. Sebagai contoh, SPSS dapat diperkenalkan dalam mata kuliah Aplikasi Komputer dan selanjutnya digunakan dalam penugasan di mata kuliah Statistik. Demikian juga dengan software akuntansi seperti Myob dan Accurate yang diajarkan di mata kuliah Komputer Akuntansi seyogyanya dapat digunakan untuk mendukung praktik penugasan di mata kuliah Akuntansi Keuangan. Penggunaan software secara komprehensif dalam berbagai mata kuliah yang relevan diharapkan dapat meningkatkan tingkat penguasaan dan ketrampilan mahasiswa dalam teknologi informasi.

\section{Kepuasan Mahasiswa terhadap Pengajaran ICT}

Sebagian besar responden $(39,13 \%)$ menyatakan bahwa secara umum mereka bersikap netral, yaitu tidak merasa puas maupun tidak puas, terhadap perkuliahan di prodi Akuntansi FE UNY terkait dengan pembekalan ketrampilan teknologi informasi/software. Di sisi lain, jumlah responden yang merasa puas (28,70\%) cukup sebanding dengan jumlah responden yang merasa tidak puas $(29,57 \%)$. Hal ini mirip dengan temuan MingLing Lai (2008) dalam sebuah survei terhadap mahasiswa Akuntansi di Malaysia yang menunjukkan bahwa mahasiswa bersikap relatif netral terhadap peran perkuliahan dalam meningkatkan ketrampilan teknologinya (mereka tidak menunjukkan kepuasan maupun ketidakpuasan). Nampaknya, pengajaran ketrampilan teknologi informasi/software belum cukup mampu memberikan kepuasan kepada mahasiswa sehingga diperlukan berbagai usaha untuk meningkatkan kuantitas maupun kualitas muatan IT dalam kurikulum program studi Akuntansi.

\section{Saran Mahasiswa terhadap Konten IT}

Penelitian ini berhasil mendapatkan beberapa masukan dari mahasiswa Akuntansi UNY mengenai muatan IT pada kurikulum dan peningkatan ketrampilan IT/software mahasiswa antara lain mengenai: peningkatan fasilitas fisik (31.75\%), penambahan muatan IT (27.78\%), pembaharuan (update) software (14.29\%), sosialisasi dan optimalisasi e-learning (11.90\%), peningkatan kualitas dosen (9.52\%), dan 
penyelenggaraan pelatihan IT bagi mahasiswa (4.76\%). Kurangnya fasilitas fisik yang memadai seperti laboratorium komputer dan akses internet yang dapat diandalkan, nampaknya perlu menjadi perhatian utama dalam proses perbaikan layanan IT. Selain itu prodi Akuntansi UNY perlu merancang tambahan muatan IT dalam kurikulum/perkuliahan, memperbarui software akuntansi yang diajarkan agar relevan dengan praktik di dunia kerja, serta peningkatan kemampuan dosen dalam penguasaan IT dan pemanfaatan e-learning dalam perkuliahan. Penyelenggaraan pelatihan IT di luar perkuliahan tentu akan memberikan manfaat yang besar mengingat mayoritas responden mengaku mempelajari software secara otodidak/mandiri (85.22\%) dan belajar dari teman $(69.57 \%)$.

Semua hal yang disebutkan di atas diperlukan untuk mendukung peningkatan kualitas program studi, namun dalam pelaksanaannya tentu harus dilakukan secara bertahap dengan memperhatikan prioritas dan ketersediaan sumber daya yang dimiliki. Dengan menindaklanjuti secara tepat masukan yang diperoleh dari mahasiswa, diharapkan dapat meningkatkan kualitas pembelajaran IT dalam perkuliahan sekaligus meningkatkan kepuasan mahasiswa program studi Akuntansi UNY.

\section{F. PENUTUP}

\section{Simpulan}

a. Mahasiswa merupakan golongan yang akrab dengan teknologi dan memiliki tingkat penggunaan ICT yang cukup tinggi. Handphone menjadi alat yang paling banyak dimiliki oleh responden $(97,39 \%)$ dan disusul oleh kepemilikan televisi $(86,96 \%)$, laptop $(86,09 \%)$ dan radio $(62,61 \%)$. Mayoritas mahasiswa telah mengenal komputer dan internet lebih dari 5 tahun dan atau 7 tahun. Akses mahasiswa terhadap internet cukup tinggi dengan mayoritas mahasiswa (64,35\%) mengaksesnya tiap hari. mahasiswa menggunakan berbagai sarana untuk mengakses internet dengan didominasi oleh penggunaan laptop/komputer di rumah $(74,78 \%)$ dan melalui handphone $(73,04 \%)$.

b. Tingkat penggunaan berbagai fasilitas/layanan berbasis IT yang disediakan oleh UNY seperti website UNY, website prodi Akuntansi, e-learning Be-Smart, e-journal dan Pojok Bursa FE UNY di kalangan mahasiswa prodi Akuntansi masih cukup rendah; hanya SIAKAD yang sudah digunakan secara intensif. 
c. Penggunaan internet oleh mahasiswa untuk mencari informasi yang berkaitan dengan tugas perkuliahan sangat tinggi yakni oleh $91,30 \%$ responden.

d. Secara umum, penguasaan mahasiswa Akuntansi UNY terhadap program aplikasi komputer seperti Microsoft Word, Excel, dan Power Point sudah cukup baik, namun pada program lain khususnya software akuntansi dan statistik penguasaannya masih kurang dan perlu untuk ditingkatkan.

e. Secara umum mahasiswa bersikap netral, yaitu tidak menunjukkan kepuasan maupun ketidakpuasan, terhadap perkuliahan di prodi Akuntansi FE UNY terkait dengan pembekalan ketrampilan teknologi informasi/software.

f. Diperoleh masukan dari mahasiswa Akuntansi UNY mengenai muatan IT pada kurikulum dan peningkatan ketrampilan IT/software mahasiswa antara lain mengenai: peningkatan fasilitas fisik (31.75\%), penambahan muatan IT $(27.78 \%)$, pembaharuan (update) software (14.29\%), sosialisasi dan optimalisasi e-learning (11.90\%), peningkatan kualitas dosen $(9.52 \%)$, dan penyelenggaraan pelatihan IT bagi mahasiswa $(4.76 \%)$.

\section{Keterbatasan}

a. Survei ini dilakukan dengan hanya menggunakan metode kuesioner sehingga data yang digunakan berasal dari jawaban responden yang sangat dipengaruhi oleh persepsi responden terhadap pertanyaan yang diajukan.

b. Analisis yang dilakukan cukup sederhana, yakni analisis deskriptif, sehingga hanya menyajikan pemaparan terhadap data yang diperoleh dan kurang mampu memberikan penjelasan mendalam mengenai kondisi sesungguhnya di lapangan.

\section{Saran}

1. Bagi institusi (prodi, jurusan, fakultas, dan universitas)

a. Meningkatkan sosialisasi dan pemanfaatan layanan ICT yang telah disediakan seperti website UNY, website prodi, e-learning be-Smart, e-journal, dan Pojok Bursa.

b. Meningkatkan fasilitas fisik yang mendukung pemanfaatan IT untuk pembelajaran, misalnya kelengkapan laboratorium komputer, akses WIFI yang lebih cepat dan mudah di kampus.

c. Meningkatkan muatan IT dalam kurikulum Akuntansi UNY baik dengan menambah mata kuliah baru maupun mengintegrasikan IT ke dalam mata kuliah yang sudah ada. 
d. Meningkatkan kualitas dosen dalam penguasaan dan penggunaan IT dalam pembelajaran melalui kegiatan training yang terprogram.

e. Menyelenggarakan pelatihan ICT secara berkala untuk mahasiswa; organisasi kemahasiswaan dapat diajak bekerjasama untuk membantu pelaksanaannya.

2. Bagi penelitian selanjutnya

a. Untuk mendapatkan pemahaman yang lebih mendalam dan komprehensif, metode wawancara dapat digunakan dalam penelitian selanjutnya

b. Untuk menjangkau lebih banyak responden, kuesioner dapat disajikan dalam bentuk online.

c. Penelitian selanjutnya dapat melibatkan para alumni yang sudah bekerja beserta atasannya sehingga penilaian terhadap efektivitas muatan IT dalam kurikulum lebih jelas.

d. Penelitian selanjutnya dapat memperluas bahasan mengenai ICT, antara lain mengenai jenis informasi dan bagaimana penggunaan informasi yang diperoleh mahasiswa dari internet serta efektivitas penggunaan internet dan layanan IT lainnya untuk tujuan akademis.

\section{G. DAFTAR PUSTAKA}

Agboola, Abdulhameed Kayode. Assessing Awareness and Peceptions of Academic Staff in Using E-Learning Tools for Instructional Delivery in a Post-Secondary Institution: A Case Study. The Innovation Journal: The Public Sector Innovation Journal, Volume 11 (3), article 4. Diakses dari http://www.innovation.cc/scholarly-style/agboola4k.pdf pada 13 Maret 2012.

Bagranoff, NA., Simkin, MG., dan Strand, CS. 2008. Core Concept of Accounting Information Systems: Tenth Edition. John Wiley \& Sons, Ltd.

Lai, Ming-Ling. 2008. Technology readiness, internet self-efficacy, and computing experience of professional accounting students. Campus-Wide Information Systems, Vol.25, No.1, pp.18-29. Diakses pada 20 Maret 2012 dari http://203.68.252.38:8080/c/document_library/get_file?p_1_id=12065\&folderId=2 6342\&name=DLFE-466.pdf

Selwyn, N. 2008. An investigation of differences in undergraduates' academic use of the internet. Active Learning in Higher Education, Vol 9 (1):11-22. Diakses dari 
http://peer.ccsd.cnrs.fr/docs/00/57/19/67/PDF/PEER_stage2_10.1177\%252F1469 787407086744.pdf pada 6 Agustus 2012.

Picot, A., Ripperger, T. \& Wolff, B. 1996. The Fading Boundaries of the Firm: The Role of Information and Communication Technology. Journal of Institutional and Theoretical Economics (JITE) [Online] 152 p.65-79. Diakses pada 25 Agustus 2011 dari http://www.im.ethz.ch/

Resnick, M. 2002. Chapter 3: Rethinking Learning in the Digital Age. The Global Information Technology Report 2001-2002, 32-37.

Roca, et.al. 2006. Understanding e-learning continuance intention: An Extension of the Technology Acceptance Model. International Journal Human-Computer Studies, 64, 683-696.

Setyarini Santosa. 2002. Electronic Commerce: Tantangan Kompetensi Akuntan dalam Menghadapi Isu Internal Kontrol. Jurnal Akuntansi \& Keuangan Vol. 4, No.1: 36:53. Diakses pada 25 Maret 2012 dari http://puslit.petra.ac.id/journals/accounting/

Sri Maharsi. 2000. Pengaruh Perkembangan Teknologi Informasi terhadap Bidang Akuntansi Manajemen. Jurnal Akuntansi \& Keuangan Vol.2, No.2: 127 - 137. Diakses pada 25 Maret 2012 dari http://puslit.petra.ac.id/journals/accounting/ 